\title{
The International Comparison of Colleges and Universities Precision Subsidization System Based on Shared Concept
}

\author{
Yang $\mathrm{LI}^{\mathrm{a}}$ and Zhen-Xiang TIAN* \\ Zaozhuang University \\ a434591582@qq.com \\ ${ }^{*}$ Corresponding author
}

Keywords: Colleges and universities, Sharing development concept, Precision subsidization system.

\begin{abstract}
The rapid development of the higher education enterprise urgently needs to be matched with the colleges and universities precision subsidization system. The concept of Shared development, which was put forward on the fifth plenary session of the 18th CPC central committee, has the extremely important guiding significance for the reflection and consummates our country university funding policy, build more conducive to realize education fairness and social development subsidization system,. Based on the concept of Shared development perspective, the typical countries of college students precise subsidization system is analyzed,in order to improve the precision in colleges and universities subsidization system in our country, promote the reform, development and achievements sharing.
\end{abstract}

\section{The Introduction}

To enhance the degree of precision subsidization of student in colleges and universities is an important way to improve the efficiency and quality of financial aid. Since the 18th national congress of the communist party of China (CPC), the central government has put forward the requirement of "targeted poverty alleviation" and raised higher requirements on education poverty alleviation. The fifth plenary session of the 18th CPC central committee put forward the five concepts of development. The concept of Shared development should serve as an important guiding principle to optimize the allocation of education resources and realize the fairness of education. Implement in the field of higher education, an urgent need to share development concept to guide college students to subsidization system, efforts to build a precise subsidization system, thus further realize the fair education opportunities.

At present, there is less research on the precision of student financing in colleges and universities, and more focus on the macro level. Bangfei Pan (2015) sum up that the factors, which influence the precision of college students, are the contradiction between financial aid and student demand, policy regulation and operation variability [1]. Yuanhang Zhang (2016) conclude precision subsidization as the object precision, demand precision, form precision and efficiency precision [2]. Yunbo Liu and Hua Bai (2016) analyzed the value orientation of the political, economic and education dimensions of precision financing [3]. The history of student financing in foreign universities is much longer, and the foreign countries, such as Britain, the United States, Japan, Russia and Australia, have formed a different system of student funding in universities [4]-[9]. The related research is comparative study of national subsidization system, though many foreign subsidization system design of precision guidance, our country university student financial assistance, but in the concept of Shared development under the guidance of college students funded research is rarely accurate. From what has been discussed above, under the concept of Shared development perspective, through the national subsidization system design, the comparative analysis of different mode of advantages and bottlenecks, help for precision in colleges and universities to provide reference to establish the precision subsidization system in our country. 


\section{The System Design for Countries to Realizate the Precision Subsidization System}

Since the middle ages, the concept of student funding has evolved many times. The early ideas include charity and religious philosophy, the equality of life and the concept of national interest, the right to education and the cultivation of cadres. After the second world war, the concept of human capital investment and higher education equality of opportunity became popular, the idea of equality of opportunity for aid policy provides a legal basis, concept of human capital investment provide a basis for the economic value in aid policy. In the 1980s, the concept of fairness and development became the new guiding principle, which required the cost-sharing principle of education and the return on investment of education [10]. Under the guidance of the concept of fairness and development, countries actively explore how to improve the precision level of university funding, thus covering a wider population at a lower cost. The specific system design is summarized in the following aspects:

(1) The overall management of funds for the subsidization system of university students

With the development of economy and society, it is a long-term trend to diversify the source of financial resources for college students. In practical work, as a result of the various funding sources funds usually additional independent standard of recipients, the end result is that funding is easy to concentrate on a few families particularly difficult students, and conduct and learning good students in particular, coverage is difficult to secure funding. The United States, Japan, France and other countries manage through different forms of funds and solve these problems better.

The subsidization system of American graduate students is characterized by "omni-directional funding", with diversified sources of funds, diversified forms and wide coverage. Because of the diversity of sources of funding for college students in the United States, the scientific nature of the allocation of funds is higher, so the country adopts the "Financial Aid Package". Aid packages in short is to plan as a whole all projects (including grants, scholarships and student loans, work-study job income, etc.), on the basis of assessment to recipients according to established rules, provide match the recipients to bear ability and economic needs of specific projects. This system design can promote the realization of education equality and the principle of cost sharing [5].

The funding source of the Japanese university students' subsidization system is dominated by government funds, especially the central government funds. The funding forms are mainly subsidized with student loans and complemented with the scholarships. It is worth noting that the country student loans financing source is a governmental funds, run by independent policy institutions, interest-free loan ratio is higher in student loans, aid-receiving students after graduation can satisfy certain conditions for full or partial reimbursement immunity [8].

All kinds of postgraduate funding in France are managed and distributed directly by university student affairs management center (CNOUS), not through university. At the same time, all student loans are guaranteed by the state, which ensures that the students with financial difficulties are more likely to get loans [10]. In the $1980 \mathrm{~s}$, as a result of college enrollment growth and recession, the difficulty of public resources are insufficient to subsidize all full-time students, the Australian design for Higher Education to undergraduates Contribution plan (who Education Contribution Scheme) and in the service of graduate student Education loan program (Postgraduate Education loans Scheme), two kinds of loan funds allocated by the government, students reimbursement according to their income after graduation [6].

(2) A relatively perfect evaluation system for financing needs

The evaluation of the financing needs of students with family difficulties has been an important factor restricting the precision of the university subsidization system in China. Countries such as the UK and the United States attach great importance to the assessment of the applicants and establish a highly standardized and highly operational evaluation system for applicants.

British graduate student aid system is characterized by "funding" after evaluation, first, the government of the applicant's accommodation, living area and to evaluate the information such as annual family income, and then different amount of student loans and living subsidy. During the grant of academic aid, assessment of the applicant's academic status and research projects [10].

The "package" on the premise of normative evaluation system, the same assessment contents 
include students studying cost (tuition and fees, room and board, transportation, etc.) and family (family income, family property, family, health, etc.), the college board is responsible for the calculation of different areas and different colleges to study cost, family situation in different areas of the reference indicators and be published. Students are also required to report on other financial support in a timely manner, so that the school can dynamically adjust the amount of funding [5].

Since 1974, Australia has abolished the old practice of issuing scholarships based on academic performance standards and instead implemented the Tertiary Education Assistance Scheme. The plan calls for an investigation into the state of the family's economy before providing a living Allowance to college students, who qualify as a Means - tested Allowance. This plan can significantly improve the accuracy of education funding, thus making the national allocation more effective [6].

(3) More pertinence special funding schemes

In addition to the universality of funded projects, in order to solve a specific problem or to guide college students professional choice, countries can also, less developed areas to establish special disadvantaged groups in particular the funding plan. Actively explore the reform of the system of scholarship in Australia, for example, in the $1980 \mathrm{~s}$ have been added for more targeted the Commonwealth Education Costs Scholarships and Commonwealth's Accommodation Scholarships, in addition to the outstanding achievement require the applicant, the former tend to low-income families and indigenous students, which focus on students' Accommodation Costs in rural and remote areas [6]. Similar special funding policies have been designed for students in India's "tabby caste" and "tabled tribes".

Countries such as Russia, Chile and Colombia have taken the form of education, a form of funding for college students. The government issued education certificates to students according to specific rules, and students chose education institutions and deducted the tuition fees from education. Education was cashing in cash with government departments. In this form, the optimal allocation of financing funds is realized. [9]. This is very different from the usual practice of allocating the scholarships to regions, schools, departments and classes according to the fixed proportion. In fact, the distribution of family difficulty students has some randomness, and it is difficult to realize the equalization of difficult student funding by assigning the financial aid index to the class. In the education model, "money goes with people", and the precise approach of funds to people is of great significance to our country.

(4) Strict student loan recovery and relief system

In order to avoid the excessive application of student loan, most countries pay more attention to the student loan repayment after graduation. The common practice is to hook up with personal credit and use the tax system to recover. At the same time, it is also common for graduates who have difficulties in repayments, deferred repayment and partial deductions. Such as the use of its perfect tax system involved in the recycling of student loans, repayment ability, and fully consider graduates income payments are needed after reaching a certain standard, and reimbursement amount does not exceed a certain percentage of revenue, reimbursement deadline is more flexible, the longest of 25 years. Korean student loans are complemented by loans of national preferential interest rate loans and commercial insurance loans. The loan conditions are strict and the debt recovery system is complete, so the default rate of student loans is low [9].

\section{Policy Recommendations}

Based on the perspective of sharing ideas, to college students, summarized the financing system of the system design and comb, can be found accurately the level of financing system in colleges and universities still needs to be improved, domestic short board is mainly manifested in aid to poor money management plan as a whole, weak aid-receiving students family situation assessment system, student loan recovery system is not sound, etc. In view of the above problems, the author puts forward the following Suggestions on how to further improve the precision subsidy system of colleges and universities in China.

First, the concept of sharing is guided to further improve the precision level of university 
subsidization system. At present, the university subsidization system in China is confronted with the common problems of "one-size-fits-all" and "per-person index" of funding. The coverage of university students' funding is not wide enough and the degree of precision is low. Accurate localization support system should be based on more accurate student family economic information, building including civil affairs, social security, tax, credit, and other departments of the comprehensive information sharing network, real screen is really necessary to support the difficult student list, at the same time, strengthen information tracking, build a recipient information dynamic monitoring and dynamic adjustment mechanism, realize the recipient into the, ensure all kinds of financial aid play their role. On the basis of this, we will explore and improve the structure of the financing system. To change the current mode of allocation of funds, establish a cross-regional finance unified management mechanism, and explore the regional dynamic adjustment mechanism of financing allocation. To strengthen the tracking of difficult student graduates visit, for life has difficulty of individual university graduates, can reduce the requirement of graduation six years to pay off the loan, extension and reduction on their student loans.

The second is to optimize the current funding policy, and clearly distinguish the functions and boundaries of awards and grants. The scholarship will be based on the academic performance and other factors as the main criteria, which are mainly spiritual rewards and material rewards. The financial aid system should reflect the sharing concept, increase the investment, expand the financial aid coverage, and focus on the family members, remote areas and minority students. We should make efforts to avoid the allocation of financial aid in the college student funding practice, give full play to the incentive of the scholarship, and avoid the dissimilation of scholarship. We will increase the proportion of grant funding in fiscal expenditures and encourage enterprises and competent individuals to set up student funds to promote the sharing of economic and social development outcomes.

Third, we will intensify the efforts of work-study students to explore ways to provide work-study jobs through marketization. At present, work-study jobs mainly focus on campus health, etc., with low technical content, personnel selection and compensation setting. We should strengthen the exploration of university-industry cooperation, encourage enterprises to set up work-study posts that are more relevant to students' majors, and gradually realize the pay-for-work, through subsidies for cooperative enterprises and other means. Special funds will be set up to pay for difficult students' participation in school teaching and research assistance. Finally, the proportion of the income of work-study students in the college students' financing system will be improved, and the public share of education resources will be realized.

\section{Reference}

[1] Pan Bangfei. Impact analysis and response strategy of college students' precision factors [J]. High education journal, 2015(5):51-52.

[2] zhang yuanhang. On the "precision financing" of college families with financial difficulties [J]. Ideology theory education, 2016(1):108-111.

[3] Liu Yunbo, Bai Hua. Precision funding: new thinking of university student funding work [J]. Education review, 2016(2):67-70.

[4] Zhang popularly. Research on American college students' funding policy [J]. Higher education research, 1997(6):88-93.

[5] Zhao Liwei. The system of "subsidy package" funded by American college students [J]. Comparison of education research, 2005, 26(2):55-56.

[6] Ge Yinghui, Zhu zhiping. Australian university student funding policies and changes [J]. Comparative education research, 2006, 27(6):45-49. 
[7] Zou Shuliang, Huang Jianmei. Comparison and reference of Chinese and English college students' subsidization system [J]. Hunan social science, 2010(1):164-166.

[8] Xu Guoxing. Study on the student subsidization system of education stage after Japanese obligations [J]. Education and economy, 2010(2):69-72.

[9] Li Sensheng, Nie Jiayong, Chen ruhuan, et al. Comparative study of higher education subsidization system at home and abroad [J].education accounting research, 2011(6):30-41.

[10]Chen Meng, Wang Fei,et al. Comparative study of graduate fee system and subsidization system in developed countries [J]. Degree and postgraduate student education, 2014(5):62-66.

[11]Zhu Huifang. Ideal and choice - international comparative study of college funding policies. Comparative study of education, 1998(6):53-54. 